\title{
A BIBLIOMETRIC ANALYSIS ON HALAL COSMETICS OVER TWENTY YEARS
}

\author{
NOR AZRINI NADIHA AZMI ${ }^{1}$, NURUL AUNI MOHD NOOR*, AMAL A.M. \\ ELGHARBAWY ${ }^{3 *}$ \\ International Institute for Halal Research and Training (INHART), International Islamic University \\ Malaysia, Jalan Gombak, 53100 Kuala Lumpur, Malaysia. \\ *Corresponding author: amalgh@iium.edu.my
}

(Received: 31 $1^{\text {st. }}$ May. 2020, Accepted: 30 ${ }^{\text {th }}$ Dec. 2020, Published on-line: $15^{\text {th }}$ Jan. 2021)

\begin{abstract}
Purpose - Halal cosmetics area is progressively increasing these days. This bibliometric analysis is intended to systematically evaluate the research to brief researchers about the trend of halal cosmetics field. This paper also discloses the limitations of the studies in the area. Design/methodology/approach - This paper adopted bibliometric and network analysis to evaluate the research area. A total of 82 documents obtained from the Scopus database are extracted and analysed. Findings - The paper reports the type of documents available, the years published, authorship and geographical distribution of the published documents in the halal cosmetics area. From the keyword analysis, it is found that the most used words are halal cosmetics, halal, cosmetics, purchase intention, Malaysia, and Islamic marketing. Research limitations/implications - This bibliometric study is conducted using Scopus database; however, Scopus might possibly omit some publications, thus, authors might not report the missing studies. Halal cosmetics are still in the early years of publications, and only 82 published documents were analysed in the study. Originality/value - There is no study reported on the network analysis and bibliometric study techniques in the area of halal cosmetics.
\end{abstract}

KEYWORDS: Halal cosmetics; Bibliometric analysis

\section{INTRODUCTION}

The Arabic word halal means 'permissible' or 'lawful', while its opposite, Haram, means prohibited or unlawful, (Hanapi \& Khairuldin, 2017). The general understanding is that halal products should not be contaminated with pork or alcohol and that livestock should be slaughtered following the Islamic Syari'ah law. However, as stated by other literature from Alzeer et al. (2018), the halal realm is not solely focused on foods but may extend to all consumables, such as toiletries, pharmaceutical, cosmetics and services including finance, investments, and business.

Other than the halal food industry, halal cosmetic products and pharmaceuticals are also of high demand, with 2.4 billion Muslim end users in the whole world. The halal market is 
expected to increase year by year globally. As long as it is not made from constituents derived from or containing pig, reptiles, predatory animals, parts of the human body such as hair, blood, carrion, and insects, all cosmetic products are considered halal. If a cosmetic ingredient needs to be derived from a lawful animal, it must be slaughtered following the Islamic law to be considered halal. It is known that halal products are fundamental for all Muslims. Despite that, non-Muslim consumers also prefer halal products as they find halal products are of higher quality, (Sugibayashi et al., 2019). This is fact-based as producing a halal product requires meticulous, accurate and attentive steps starting from raw material until it is secured in the consumer's hand. Halal products also prioritize the safety of products so that the products' efficacy increased and are considered more eco-ethical and natural in every manner, (Hashim \& Mat Hashim, 2013).

Many, products that claimed to be halal are believed by many to be eco-friendly and more ethical with better production practices. This complies with the 'tayyib' concept, which means good or desirable. Halal certification increase ethical standards, and not only that, it covers all aspects in better form, from economy and business management, community, environment, and manufacturing process. Every halal company that faithfully obeys the halal requirements are directly or indirectly withstanding against environmental pollution, cruelty and starting to initiate green marketing, (Aoun \& Tournois, 2015). Not only executing religious requirements, but halal products also demonstrate more natural and eco-friendly ways, which portrays that they are protecting the universe wholly.

The current trend of purchasing products by consumers concerns about the halal-certified products. Consumers were becoming more conscious in purchasing products to prioritize the halal-certified products due to safety and hygiene purposes, (Fahmi, 2017). Fahmi, (2017) also added that the need to purchase Halal certified products was due to the increasing level of awareness and obligation about purchasing halal products among Muslim consumers. This shows that consumers' attitudes influenced the intention of purchasing halal-certified products. As explained by Zaimah et al. (2018), consumer's attitude toward purchasing halal-certified products was due to the understanding of the concept of halal, which has been stated in the Holy Quran, which it can bring goodness and benefits. Even non-Muslim consumers started to purchase or consume halal-certified products as the benefits have been proven through scientific research, (Zaimah et al., 2018).

In another article by Ngah et al. (2019), it was stated that halal cosmetics manufacturers have started to comply halal concept even in the transportation services of their products. Cosmetics manufacturers had started to apply halal transportation services due to the awareness and consciousness to perceive benefits, provide safe transportation environment, and preserve intention of application, (Sugibayashi et al., 2019). In research conducted by Ngah et al. (2019) the increase of intention in adopting halal transportation services was due to the increase of perceived benefits provided by the halal transportation provider that will be received by the manufacturers. Tieman et al. (2012) described halal supply management principles, which involved supply chain resources, supply chain network structure, and supply chain business processes. The halal supply chain is a crucial factor even in the cosmetics industry as it ensures the product is undoubtedly halal, right from the manufacturing process until the product is in the hand of the consumers.

Meanwhile, Samori et al. (2014) described halal standards' development as a contemporary standard in modern lifestyle. Halal standards should be developed as guidance or standard in which manufacturers must achieve to obtain halal recognition for their products. The 
implementation of halal standards in cosmetics allowed committee from Department of Islamic Development Malaysia (JAKIM) to critically evaluate cosmetics products that were eligible for halal certification, (Jusoh et al., 2016). With that being said, cosmetics halal standards also served as a medium for monitoring and enforcing halal certification obligation in a way failure to comply with those standards resulting in serious actions taken to certificate holders.

After all, even researches are actively being done and reported in the halal area, to the best of the authors' knowledge, no study has been done using bibliometric and network analysis techniques in the subject area of halal cosmetics. Thus, this paper will utilize bibliometric analysis to review the available literature in the area of halal cosmetics from the year 2000 until recently (2000-2020). The bibliometric analysis is intended to systematically evaluate the research to brief researchers about a specific area's trend.

\section{METHODS}

This paper emphasized the bibliometric analysis used to explore and classifying the literature reported in the halal cosmetics area. The bibliometric study aimed to quantitatively analyze halal cosmetics' research area to understand how the area had progressed in twenty years. The research methodology implied in this study is shown in Figure 1. The first step in conducting this analysis was defining the analysis topic by setting four research questions: How many publications have been published related to halal cosmetics?; Which country contributed to the most publications regarding halal cosmetics from the year 2000 until 2020?; When are the active years of publication regarding halal cosmetics?; What is the relationship between halal and cosmetic?. The second step was identifying keywords and time frame for the analysis, and in this analysis, the keywords identified were 'halal' and 'cosmetics' meanwhile, the time frame was set from the year 2000 until 2020 in which the correspondent years were targeted to be the years active of halal cosmetics publications being published. The third step was the selection of data surface in which Scopus database was used while conducting this analysis. The fourth step was data retrieval, in which all data from Scopus database were exported in excel (CSV) format for further analysis. The fifth step was including analysis of data in which summary tables, related calculations, and bibliometric measures were produced. The sixth step was visualizing results obtained in the form of tables, geographical maps, and VOSviewer. Geographical maps visualized maps with detailed descriptions of graphs which contained two important characteristics, the distance between variables and proximity between variables, (Melo \& Queiroz, 2019). Meanwhile, VOSviewer provided three different visualizations, network visualization, overlay visualization and density visualization in which the data was exported from citation database such as Scopus. The last step in conducting this analysis was evaluating the findings by referring to other journals as validation for the results obtained as well as discussing the findings for better understanding.

\section{BIBLIOMETRIC ANALYSIS AND DISCUSSIONS}

For this study, the Scopus database of 82 documents related to halal cosmetics was downloaded in a.csv (comma-separated value) file format according to the requirements VOSviewer, the program used for data analysis. The data retrieved from the downloaded SCOPUS database is the year published, author names and affiliations, keywords, languages 
used, and geographical distribution of the articles. The same information of the halal cosmetics SCOPUS Scopus database is also saved in Excel format to generate graphs and tables to determine the, year of database trends, for example, the document type, year published, and keywords frequency in 


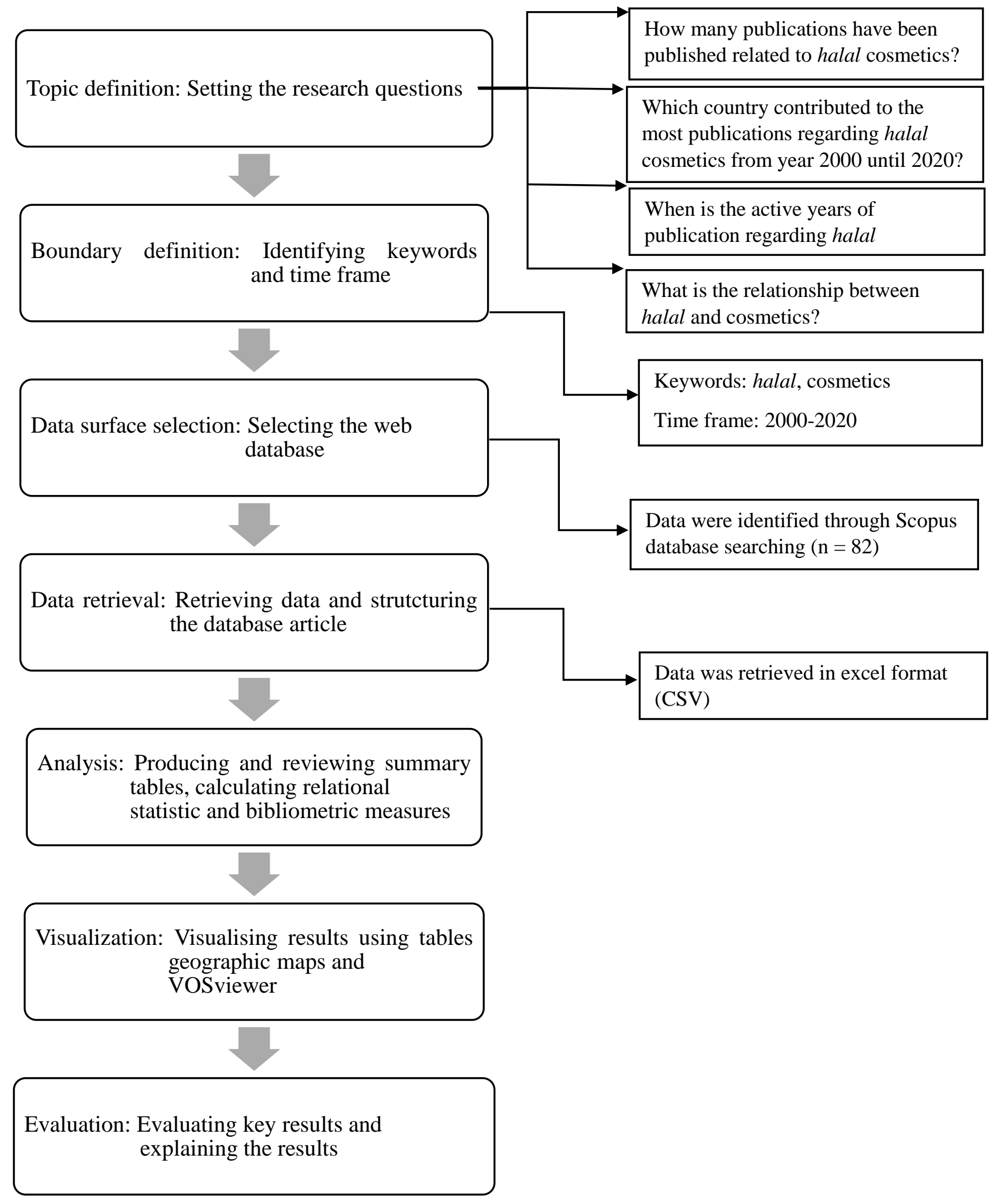

Fig. 1: Research methodology adopted in the bibliometric analysis on halal cosmetics over twenty years. 
the documents. The following sub-sections present the document and source types of publications, language used in documents, keywords frequently used, and geographical distribution as acquired from the bibliometric analysis.

From the analysis that had been done, it can be said that Halal as a whole research area has high potential as the demand for halal is increasing year by year. However, other halal research areas such as halal cosmetics are limited because people tend to associate halal with only food, but not as a way of life. This is tally with a bibliometric review from, (Haleem et al., 2020), which stated that researchers are more interested in halal's food aspect and inferred that halal is only for Muslims. The most active country publishing in halal cosmetics is Malaysia, followed by Indonesia. This is in agreement with the increasing market of halal cosmetics in both countries. Malaysia is also one of the largest Malaysian export markets compared to Southeast Asian neighbors for halal products. Though the halal area is being explored nowadays, halal cosmetics' progress is still in the early stage. Sugibayashi et al. (2019) stated that non-halal cosmetics manufacturers still govern cosmetics production, which can cause doubt for the Muslim consumers because the production process might not meet the halal requirements. Thus, there is a strong need to introduce halal concept worldwide, not only in Muslim countries. This is where researchers from all the countries should alleviate the works in the halal cosmetics area.

\subsection{Document and Source Types}

The document and source types are extracted using Excel. As listed in Table 1, the most frequent document type for halal cosmetics area is article with $80.49 \%$, followed by conference paper $(7.32 \%)$, book chapter $(4.88 \%)$, review (3.65\%), and book, note, and short survey with $(1.22 \%)$ each. The dominating source type is mostly journals. This might be because there is increasing demand for halal cosmetics topics in various journals. Halal conferences around the world keep expanding, and this might be the factor conference papers comes in second. Halal cosmetics topic written in book, note and short survey is the least as it might be more challenging to publish in these types of documents. The source type analysis is quite similar to the document type, which is portrayed in Table 2.

Table 1: Document type.

\begin{tabular}{lll}
\hline Document Type & Frequency & \% (N=82) \\
\hline Article & 66 & 80.49 \\
Conference Paper & 6 & 7.32 \\
Book Chapter & 4 & 4.88 \\
Review & 3 & 3.65 \\
Book & 1 & 1.22 \\
Note & 1 & 1.22 \\
Short Survey & 1 & 1.22 \\
\hline Total & $\mathbf{8 2}$ & $\mathbf{1 0 0 . 0 0}$ \\
\hline
\end{tabular}


Table 2: Source type.

\begin{tabular}{lll}
\hline Source Type & Frequency & \% (N=82) \\
\hline Journals & 70 & 85.36 \\
Conference Proceedings & 6 & 7.32 \\
Books & 5 & 6.10 \\
Trade Publications & 1 & 1.22 \\
\hline Total & $\mathbf{8 2}$ & $\mathbf{1 0 0 . 0 0}$ \\
\hline
\end{tabular}

\subsection{Year Publication}

The first Scopus-indexed article published in the halal cosmetics area is in 2006, and then the second one took quite some time to be published in 2011. There might be less interest in halal cosmetics in the early years of the publications, but articles keep adding each year, with 2019 become the most active year for writers to publish their papers. As the millennial Muslim consumers tend to be more observant of Islamic principles, they tried to incorporate halal into their lifestyle. Thus, new opportunities are opening up in cosmetics and personal care categories. Researches might have been intently done on halal cosmetics a few years before, so in 2019 , papers are published intensively. In 2019, 21 publications were published, as stated in Table 3.

Table 3: Year of publications.

\begin{tabular}{llll}
\hline Year & Frequency & \% $(\mathbf{N}=\mathbf{8 2})$ & Cumulative Percent \\
\hline $2000-2005$ & 0 & 0 & 0 \\
\hline 2006 & 1 & 1.22 & 1.22 \\
2011 & 1 & 1.22 & 2.44 \\
2012 & 5 & 6.10 & 8.54 \\
2013 & 4 & 4.88 & 13.42 \\
2014 & 4 & 4.88 & 18.30 \\
2015 & 7 & 8.53 & 26.83 \\
2016 & 8 & 9.75 & 36.58 \\
2017 & 9 & 10.98 & 47.56 \\
2018 & 17 & 20.73 & 68.29 \\
2019 & 21 & 25.61 & 93.90 \\
2020 & 5 & 6.10 & 100.00 \\
\hline Total & $\mathbf{8 2}$ & $\mathbf{1 0 0 . 0 0}$ & \\
\hline
\end{tabular}




\subsection{Language of Documents}

The documents are actively being written in English as 81 over 82 of the publications are written in English and the remaining is in Turkish, as stated in Table 4. English is a very important international lingua franca in many places all over the globe. Undoubtedly, it is why the documents are mostly written in English. More people will understand and be aware of the halal cosmetics topic if written in English.

Table 4: Languages used for publications.

\begin{tabular}{lll}
\hline Language & Frequency* & \% (N=1114) \\
\hline English & 81 & 98.78 \\
Turkish & 1 & 1.22 \\
\hline Total & $\mathbf{8 2}$ & $\mathbf{1 0 0 . 0 0}$ \\
\hline
\end{tabular}

\subsection{Keyword Analysis}

Using VOSviewer and Excel, Figure 2 and Table 5 were obtained. From Figure 2, it can be seen from the connection that most of the words are related to each other. The size of the word shows the frequency of the words used related to halal cosmetics. For example, halal cosmetics is the largest number and is tally with the frequency of author keywords shown in table 5. The similar color of the words means similar keywords are shared between the topic. It can be seen from the color light blue in Figure 2. Islamic marketing keywords are mostly related to other keywords, such as consumer behavior and the Muslim consumer. Table 5 shows that the most frequent words used are halal cosmetics with approximately $15.12 \%$, followed by the words; halal, cosmetics, purchase intention, Malaysia, and Islamic marketing. Even though the keywords chosen are halal cosmetics, it is not surprising that halal food and halal logistics still appeared in the table. This is because the keywords might be related to each other in certain sources, such as review papers or books. Other than that, countries such as Malaysia and Indonesia also make it on the top list. These two countries might be the most active countries in halal research or publications. Keywords such as purchase intention, Islamic marketing and consumer behavior also indicate that displaying these topics is currently being studied by some researchers. There are also science-related keywords such as polymerase chain reaction, which shows that science-based research has been done although lesser than social science study on halal cosmetics. Surprisingly; the keywords fish appear three times in the author's keywords, which portrays that it could be a new alternative ingredient in halal cosmetics. From the frequency of the author keywords analyzed in this study, researchers could continue their study on existing topics or embark on new research on new topics. For instance, studies can also be focused more on science-based halal cosmetics researches. 


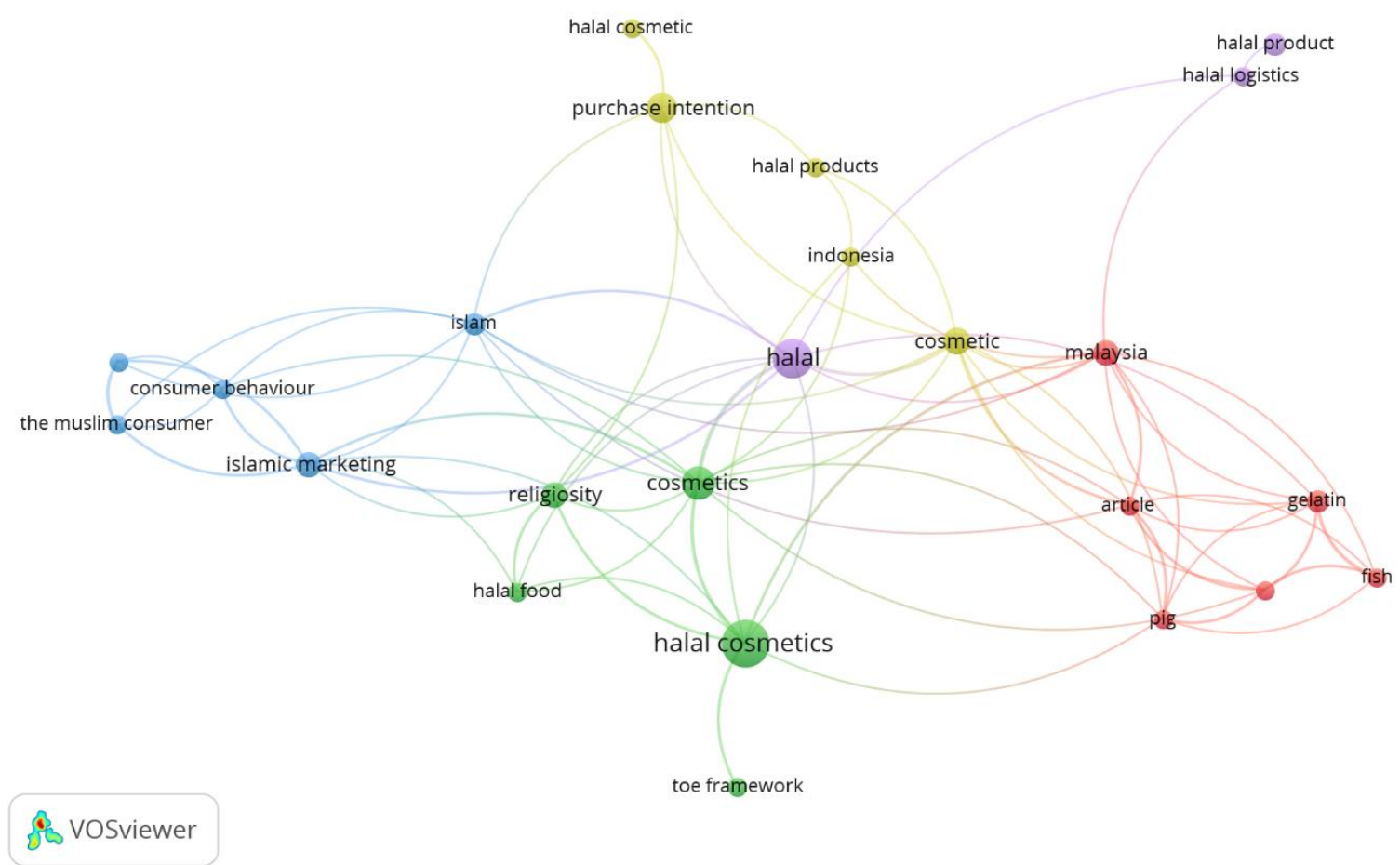

Fig. 2: Network visualization map of the author keywords.

Table 5: Frequency of author keywords.

\begin{tabular}{lll}
\hline Author Keywords & Frequency & Percent \\
article & 3 & 2.52 \\
consumer behavior & 3 & 2.52 \\
cosmetic & 6 & 5.04 \\
cosmetics & 9 & 7.56 \\
fish & 3 & 2.52 \\
gelatin & 4 & 3.36 \\
halal & 13 & 10.92 \\
halal cosmetic & 3 & 2.52 \\
halal cosmetics & 18 & 15.12 \\
halal food & 3 & 2.52 \\
halal logistics & 3 & 2.52 \\
halal market & 3 & 2.52 \\
halal product & 4 & 3.36 \\
halal products & 3 & 2.52 \\
Indonesia & 3 & 2.52 \\
islam & 4 & 3.36 \\
Islamic marketing & 5 & 4.20 \\
Malaysia & 5 & 4.20 \\
pig & 3 & 2.52 \\
polymerase chain reaction & 3 & 2.52 \\
purchase intention & 7 & 5.88 \\
religiosity & 5 & 4.20 \\
the Muslim consumer & 3 & 2.52 \\
toe framework & 3 & 2.52 \\
\hline
\end{tabular}




\subsection{Geographical Distribution of Publications - The Most Influential Countries}

Table 6 listed the top ten countries, which mainly contributed to publications related to halal cosmetics between 2000 until 2020. It can be seen that Malaysia contributed to the most publications, which covered $51.16 \%$ of the total publications, followed by Indonesia and India with $22.09 \%$ and $8.14 \%$, respectively. The huge gap of halal cosmetics publications can be discussed based on two aspects, which were top halal cosmetics producing countries and awareness for halal cosmetics in the countries. The rising of halal cosmetics brands among these countries, especially Malaysia and Indonesia, had attracted various researches conducted in this area (Che Mohd Hashim \& Musa, 2013). For example, in Malaysia, Safi was the first cosmetic brand to obtain halal certification and ranked 34 out of 170 of the most used brands globally, (Hussain, 2012).

Meanwhile, the first declared halal cosmetic brand in Indonesia was Wardah, which was rapidly exported throughout the globe, (Sukesi \& Hidayat, 2019). Besides, an increase in awareness and demand for halal cosmetics in these countries accelerated this field's studies. In Malaysia, a study conducted by Mohezar et al. (2016) revealed that most Muslim and nonMuslims consumers chose halal cosmetics products due to their confidence in the safety, pureness, and quality. In fact, $37.7 \%$ of Muslims in Indonesia were aware of using halal cosmetics products and will definitely purchase them once the products are released in the market, (Rahim et al., 2015).

Table 6: Top 10 countries contributed to the publications.

\begin{tabular}{lll} 
Country & Frequency & $\%(\mathrm{~N}=86)$ \\
Malaysia & 44 & 51.16 \\
Indonesia & 19 & 22.09 \\
India & 7 & 8.14 \\
Turkey & 3 & 3.49 \\
United Arab Emirates & 3 & 3.49 \\
United States & 3 & 3.49 \\
Iran & 2 & 2.33 \\
Pakistan & 2 & 2.33 \\
Thailand & 2 & 2.33 \\
Australia & 1 & 1.15 \\
\hline Total & $\mathbf{8 6}$ & $\mathbf{1 0 0 . 0}$
\end{tabular}




\subsection{Authorship}

The number of the author(s) for each published document and article were listed in Table 7., The top ten most productive authors according to the respective number of documents they published were listed in Table 8. It can be seen that the highest number of authors per document recorded was four authors with a frequency of 23 , covering $28.05 \%$ of the total. The least number of authors per document recorded were six authors with a frequency of two and covered $2.44 \%$ of the total. The most active authors recorded were Ngah A. H and Rohman A., with three documents published, which covered $13.64 \%$ of the total. The other eight authors recorded two documents published for each of them. The table explained some of the authors had published more documents than the others as most of their research was continuous and of the same influential institutions or organizations.

Table 7: Number of author(s) per document.

\begin{tabular}{lll}
\hline Author count & Frequency & $\%(\mathrm{~N}=82)$ \\
$\mathbf{1}$ & 9 & 10.98 \\
$\mathbf{2}$ & 21 & 25.61 \\
$\mathbf{3}$ & 16 & 19.51 \\
$\mathbf{4}$ & 23 & 28.05 \\
$\mathbf{5}$ & 8 & 9.75 \\
$\mathbf{6}$ & 2 & 2.44 \\
$\mathbf{7}$ & 3 & 3.66 \\
\hline Total & $\mathbf{8 2}$ & $\mathbf{1 0 0 . 0}$ \\
\hline
\end{tabular}

Table 8: Top 10 most productive authors.

Author's name

Ngah, A.H.

Rohman, A.

Abdinagoro, S.B.

Abdullah, N.A.B.

Ainin, S.

Al Rashid, H.

Ali, M.E.

Ali, M.H.

Anuar, N.B.
No. of documents

3

3

2

2

2

2

2

2

2
$\%(\mathrm{~N}=22)$

13.64

13.64

9.09

9.09

9.09

9.09

9.09

9.09

9.09 
$\begin{array}{lll}\text { Arbak, S. } & 2 & 9.09\end{array}$

$\begin{array}{lll}\text { Total } & 22 & 100.0\end{array}$

Figures 3, 4, and 5 were the network visualization map of co-authorship obtained using VOSviewer. Figure 3 showed the relationship between authors who published at least two articles or documents with at least two authors' citations. It can be seen that four authors met the requirements, and they were related to each other. Meanwhile, Figure 4 showed the organizations involved regarding the authors of the published articles with at least one document for each organization. Figure 5 indicated the relationship between countries and the respective authors, contributing to the publications related to halal cosmetics. It showed that Malaysia was positively related to other countries such as Indonesia, Thailand, the United Arab Emirates, and India. This is because, Malaysian halal cosmetic industry had been growing for an extended period, and most of the halal cosmetics products were being exported to these countries such as Middle East countries and ASEAN countries, consequently enabling collaborative studies to be conducted within these countries, (Mohezar et al., 2016).

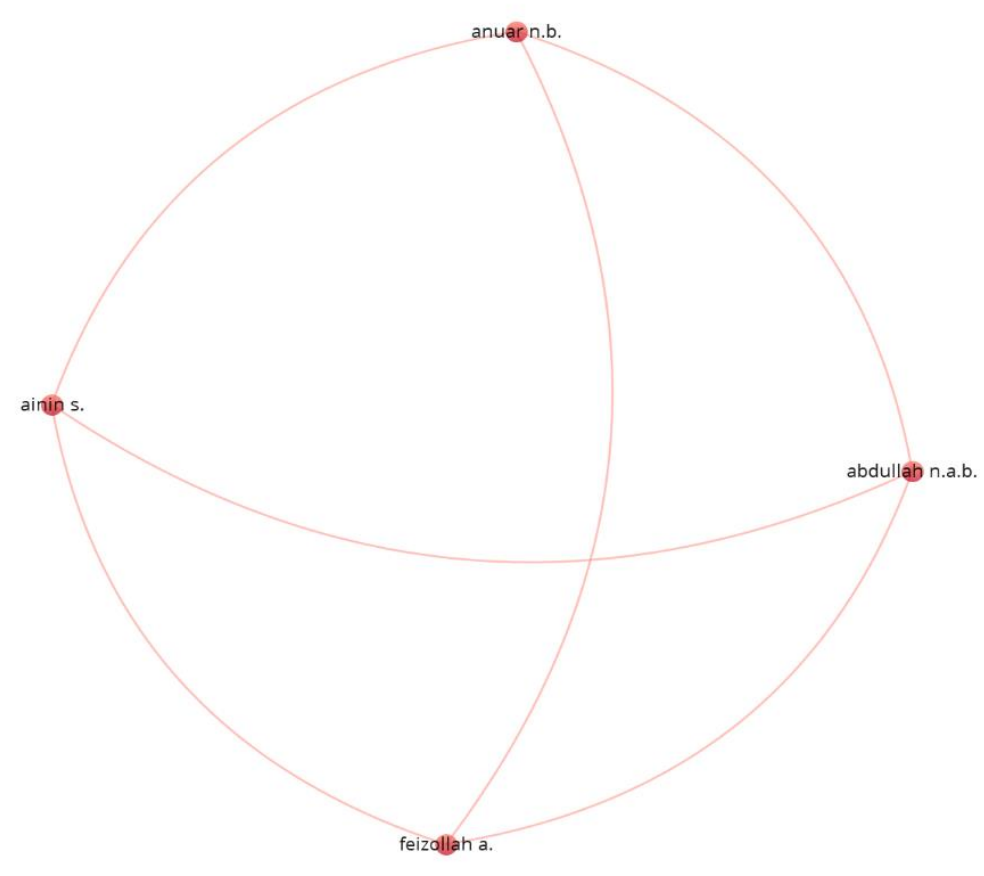

Fig. 3: Network visualization map of co-authorship.

Unit of analysis: authors

Maximum number of authors per document: 25

Minimum number of documents of an author: 2

Minimum number of citations of an author: 2 


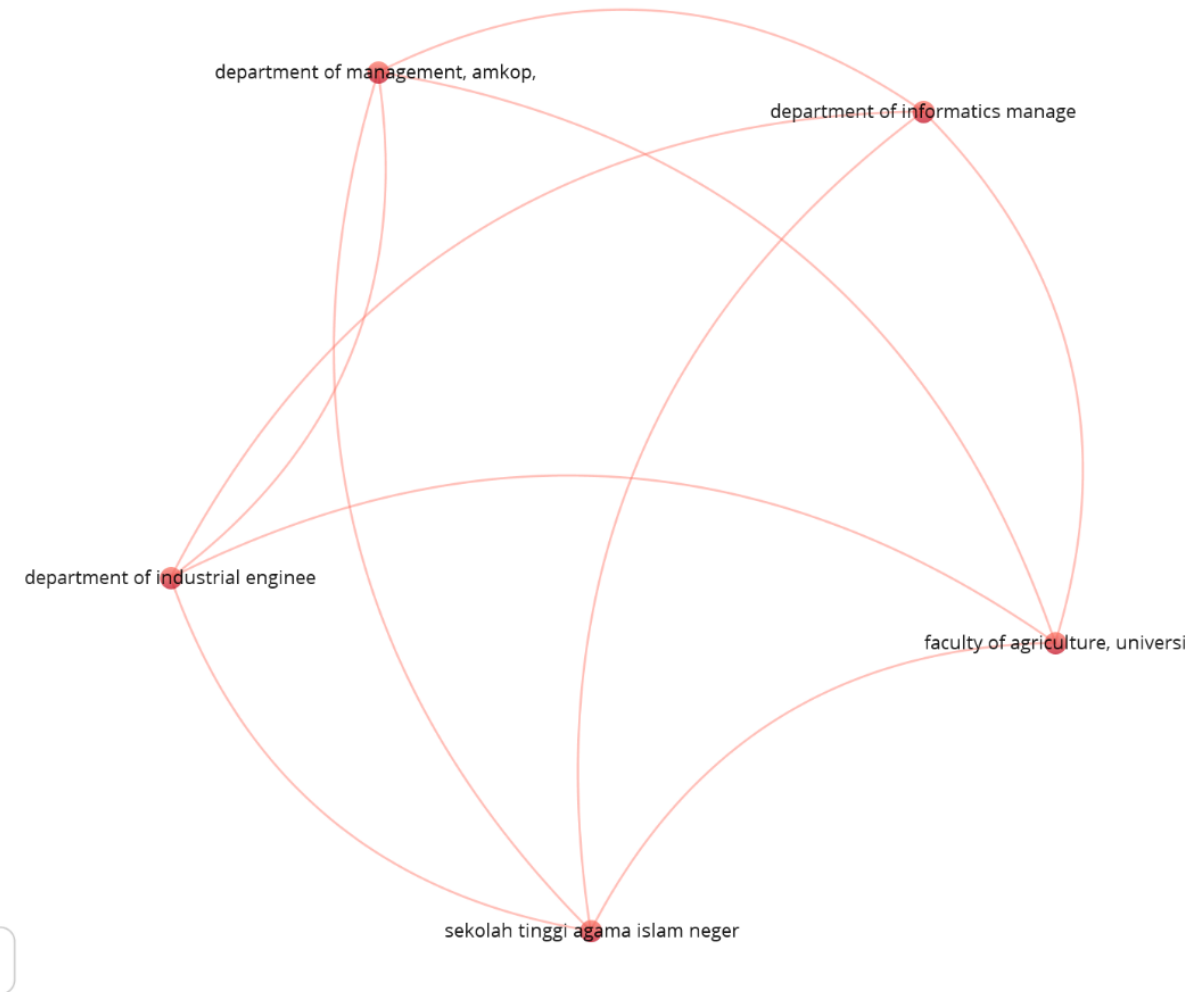

Fig. 4: Network visualization map of the most influential organizations.

Unit of analysis: organizations

Maximum number of organizations per document: 25

Minimum number of documents of an organization: 1

Minimum number of citations of an organization: 0

\subsection{Most Influential Institution}

Table 9 below listed the top ten most influential institutions with a minimum of one publication. It can be seen that Universiti Malaya and Universiti Utara Malaysia produced the highest number of publications (3), contributing to $18.75 \%$ of the total publications. Both of these universities have their own halal institute, which might impact the journal published on halal cosmetics. However, other halal institutions from Malaysian Universities do not publish their papers on halal topics might be downgrading as they might not focus their research on halal cosmetics but other topics such as food or logistics. 


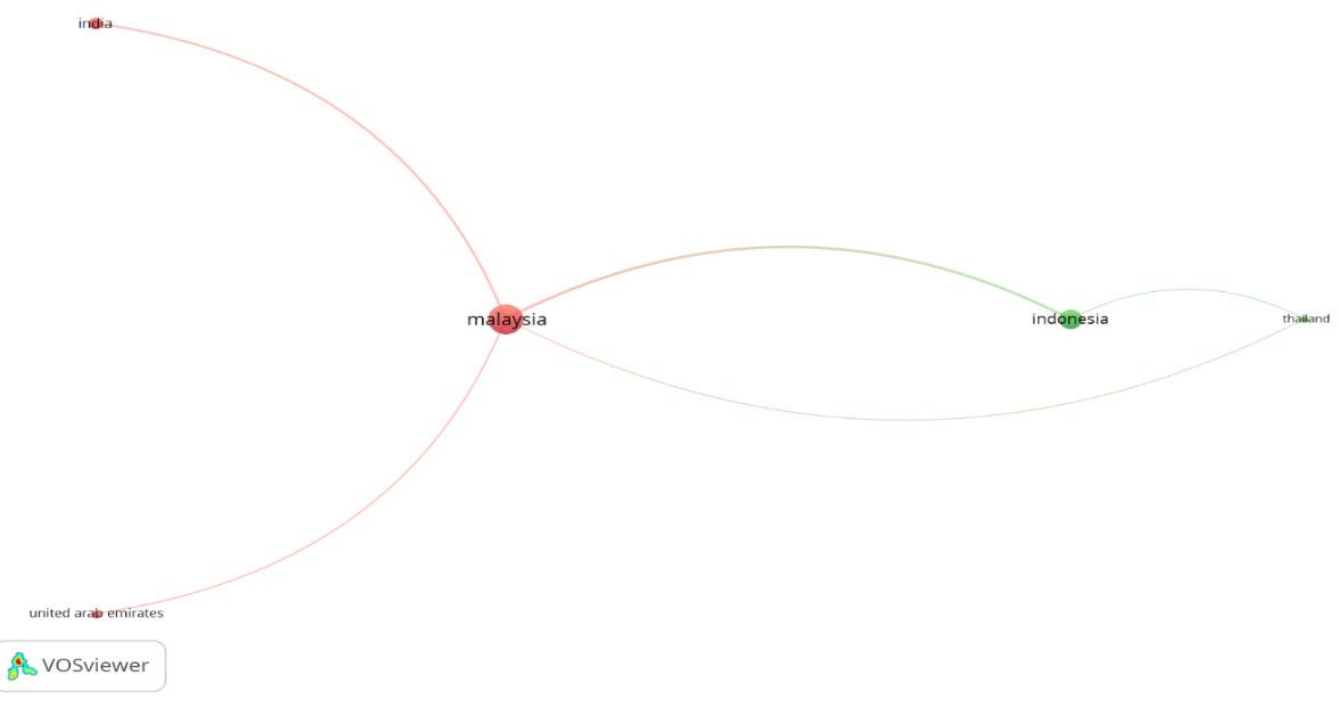

Fig. 5: Network visualization map of active countries in publishing journals in halal cosmetics.

Unit of analysis: countries

Maximum number of countries per document: 25

Minimum number of documents of a country: 2

Minimum number of citations of a country: 0

Table 9: Top 10 most influential institution with minimum of one publication.

\begin{tabular}{lll}
\hline \multicolumn{1}{c}{ Institution } & No. of publication & $\%(\mathrm{~N}=16)$ \\
Universiti Malaya & 3 & 18.75 \\
Universiti Utara Malaysia & 3 & 18.75 \\
Ministry of Higher Education, Malaysia & 2 & 12.50 \\
Pusat Pengurusan Penyelidikan dan Inovasi, UUM & 2 & 12.50 \\
Institut Pengurusan dan Pemantauan Penyelidikan, UM & 1 & 6.25 \\
Institut Teknologi Sepuluh Nopember & 1 & 6.25 \\
International Islamic University Malaysia & 1 & 6.25 \\
Korea Institute of Planning and Evaluation for Technology in & 1 & 6.25 \\
Food, Agriculture, Forestry and Fisheries & & \\
$\quad$ Lembaga Penelitian dan Pengabdian Kepada Masyarakat & 1 & 6.25 \\
$\quad$ Ministry of Agriculture, Food and Rural Affairs & 1 & 6.25 \\
\hline$\quad$ Total & $\mathbf{1 6}$ & $\mathbf{1 0 0 . 0}$ \\
\hline
\end{tabular}




\subsection{Citation Analysis}

Table 10 showed the citation metrics of the published publications related to halal cosmetics. Table 11 showed the top ten most influential articles. According to the most cited articles, the articles were arranged to the least cited articles with a minimum of ten citations. The most cited article was Intention to Choose Halal Products: The Role of Religiosity, written by Mukhtar, A. and Butt, M. M., with 129 citations since it was published in 2012. The least cited article was Exploring Antecedents and Consequences of Indonesian Muslims Youths' Attitude Toward Halal Cosmetic Products: A Study Case in Jakarta by Briliana, V., and Mursito, N. with eleven citations.

Table 10: Citation metrics.

\begin{tabular}{ll}
\hline Metrics & Data \\
Publication years & $2005-2020$ \\
Citation years & $15(2005-2020)$ \\
Papers & 82 \\
Citations & 505 \\
Citation/year & 34 \\
Citation/paper & 6 \\
Citation/author & 51 \\
\hline
\end{tabular}

Table 11: Highly cited articles - The most influential articles.

\begin{tabular}{|c|c|c|c|c|}
\hline Authors & Article title & Year & Cites & $\begin{array}{l}\text { Cites per } \\
\text { year }\end{array}$ \\
\hline Mukhtar, A., Butt, M.M. & $\begin{array}{l}\text { Intention to Choose Halal Products: The Role } \\
\text { of Religiosity }\end{array}$ & 2012 & 129 & 16 \\
\hline $\begin{array}{l}\text { Tieman, M., Vorst, J.G., } \\
\text { Ghazali, M.C. }\end{array}$ & Principles in Halal Supply Chain Management & 2012 & 80 & 10 \\
\hline $\begin{array}{l}\text { Rahman, } \\
\text { Asrarhaghighi, } \\
\text { Rahman, A.S. }\end{array}$ & $\begin{array}{l}\text { Consumers and Halal Cosmetic Products: } \\
\text { Knowledge, Religiosity, Attitude and } \\
\text { Intention }\end{array}$ & 2015 & 63 & 13 \\
\hline $\begin{array}{l}\text { Ngah, A.H., Zainuddin, Y., } \\
\text { Thurasamy, R. }\end{array}$ & $\begin{array}{l}\text { Applying the TOE Framework in the Halal } \\
\text { Warehouse Adoption Study }\end{array}$ & 2017 & 34 & 11 \\
\hline Izberk, B.E., Nakata, C.C. & $\begin{array}{l}\text { A New Look at Faith-Based Marketing: The } \\
\text { Global Halal Market }\end{array}$ & 2016 & 26 & 7 \\
\hline Aoun, I., Tournois, L. & $\begin{array}{l}\text { Building Holistic Brands: An Exploratory } \\
\text { Study of Halal Cosmetics }\end{array}$ & 2016 & 18 & 5 \\
\hline
\end{tabular}




$\begin{array}{llllr}\begin{array}{l}\text { Hussin, S.R., Hashim, H., } \\ \text { Yusof, R.N., Alias, N.N. }\end{array} & \begin{array}{l}\text { Relationships Between Product Factors, } \\ \text { Advertising and Purchase Intention of Halal } \\ \text { Cosmetics }\end{array} & 2013 & 14 & 3 \\ \text { Yener, D. } & \begin{array}{l}\text { Factors that Affect the Attitude of Consumers } \\ \text { Toward Halal-Certified Products in Turkey }\end{array} & 2015 & 13 & 3 \\ \text { Garg, P., Joshi, R. } & \begin{array}{l}\text { Purchase Intention of Halal Brands in India: } \\ \text { The Mediating Effect of Attitude }\end{array} & 2018 & 12 & 6 \\ \text { Briliana, V., } & \begin{array}{l}\text { Exploring Antecedents and Consequences of } \\ \text { Indonesian Muslims Youths' Attitude Toward } \\ \text { Halal Cosmetic Products: A Study Case in } \\ \text { Jakarta }\end{array} & & & \\ & & & \end{array}$

Figures 6 and 7 showed the network visualization map of citations related to documents and countries, respectively, using VOSviewer. It can be seen that the highly cited documents or articles in Table 10 can be supported using this map.

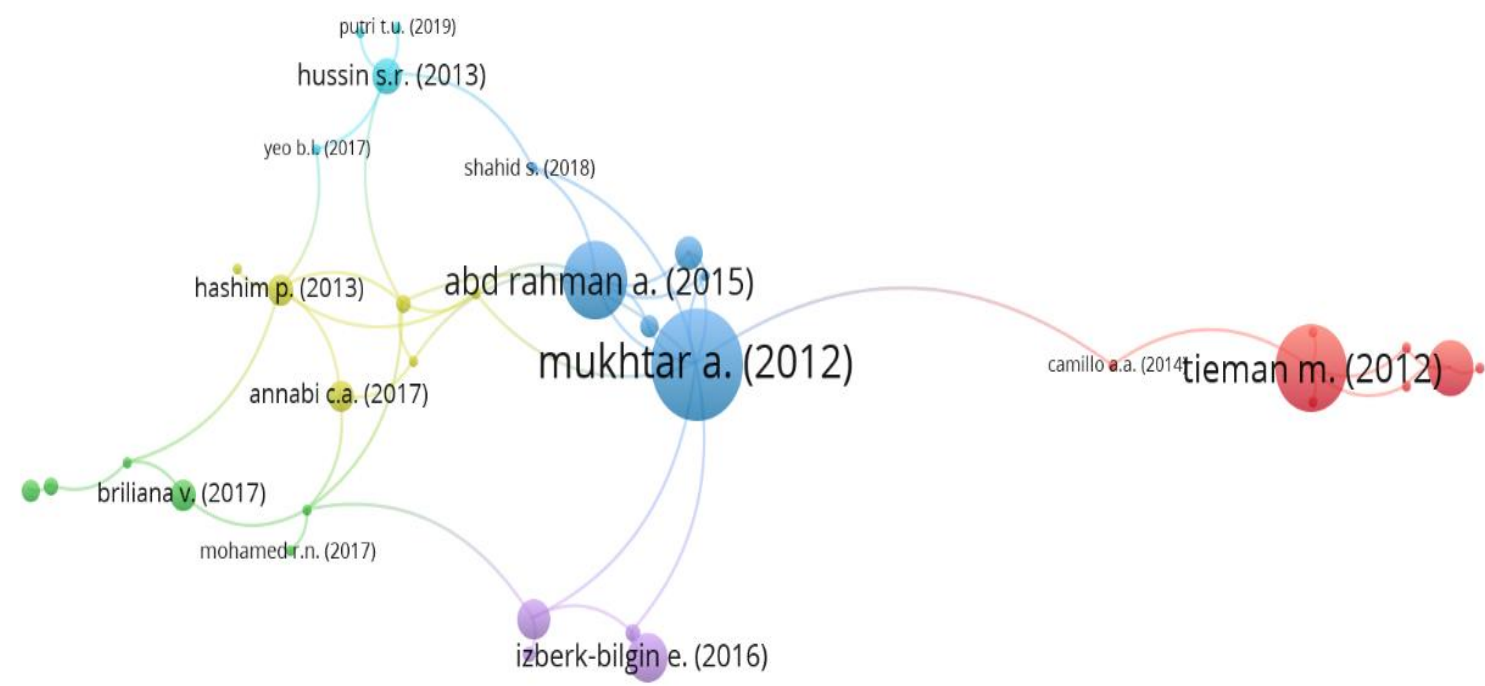

\& VOSviewer

Fig. 6: Network visualization map of citation.

Unit of analysis: documents

Minimum number of citations of a document: 0 


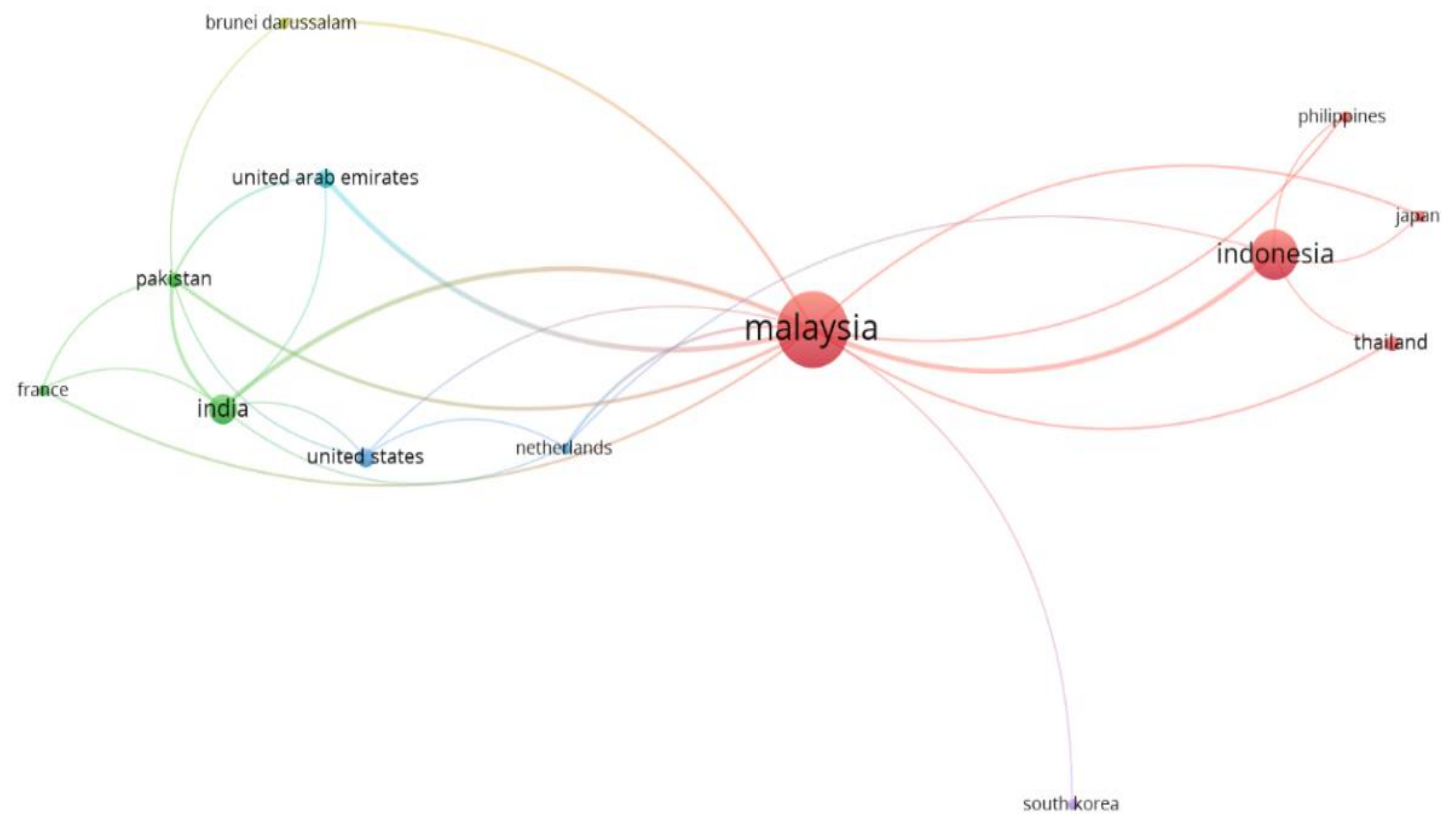

Fig. 7: Network visualization map of countries published the most

Unit of analysis: countries

Maximum number of countries per document: 25

Minimum number of documents of a country: 1

Minimum number of citations of country: 0

\section{CONCLUSION}

This bibliometric review reveals the growing interest of researchers and writers on the halal issue, especially in the cosmetics industry, in which the publication on the related subject is increasing each year covering many countries. This summarized that awareness and knowledge regarding the benefits of halal products are broadening to the entire world. This review helps the readers access the latest publications regarding halal cosmetics and the respective authors who contribute to the publications. Even though the halal issue publications are increasing; until now, only 82 publications have been published, which shows that there are still many topics related to halal cosmetics that have not been covered yet. Nevertheless, this study has some limitations, as only the Scopus database was used to conduct a systematic review and bibliometric study. 
Besides, the selection of keywords might not be accurate. Other than that, the finding shows that the first publication on the halal cosmetics topic was in the year 2006, which means that this review has a limited time frame. Thus, future research needs to be conducted and focus more on the halal issue to provide excellent references for readers. In conclusion, this paper might help researchers find the halal cosmetics area gap and increase their work in this field.

\section{ACKNOWLEDGMENT}

Authors express their gratitude the to the International Institte for Halal Research and Training (INHART), IIUM for supporting this research.

\section{REFERENCES}

[1] Alzeer, J., Rieder, U., Hadeed, K. A. (2018). Rational and Practical Aspects of Halal and Tayyib in the Context of Food Safety. Trends in Food Science \& Technology, 71, 264267. https://doi.org/10.5167/uzh-169451

[2] Aoun, I., Tournois, L. (2015). Building Holistic Brands: An Exploratory Study of Halal Cosmetics. Journal of Islamic Marketing, 6, 109-132. https://doi.org/10.1108/JIMA-052014-0035

[3] Che Mohd Hashim, A. J., \& Musa, R. (2013). Factors Influencing Attitude Towards Halal Cosmetic Among Young Adult Urban Muslim Women: A Focus Group Analysis. Procedia - Social and Behavioral Sciences, 130(2014), 129-134. https:// doi.org/10.1016/j.sbspro.2014.04.016

[4] Fahmi, S. (2017). Halal Labeling Effect on Muslim Consumers Attitude and Behavior. Advances in Intelligent Systems Research, 131, 56-62. https://doi.org/10.2991/icoi$\underline{17.2017 .26}$

[5] Haleem, A., Khan, M. I., Khan, S., Jami, A. R. (2020). Research Status in Halal: A Review and Bibliometric Analysis. Modern Supply Chain Research \& Application, 2, 23-41. https://doi.org/10.1108/MSCRA-06-2019-0014

[6] Hanapi, M. S., \& Khairuldin, W. M. K. F. W. (2017). The Halal-Green in Al-Quran: A Conceptual Analysis. International Journal of Academic Research in Bussiness \& Social Science, 7, 319-340. https://doi.org/10.6007/IJARBSS\%2FV7-I10\%2F3380

[7] Hashim, P., \& Mat Hashim, D. (2013). A Review of Cosmetic and Personal Care Products: Halal Perspective and Detection of Ingredient. Pertanika Journal of Science \& Technology, 21, 281-292.

[8] Hussain, N. (2012) A Little Empathy goes a Long Way: How brands can engage the American Muslim consumer. American Muslim Consumer Research, 2-4. https://doi.org 10.1016/j.sbspro.2014.04.016

[9] Jusoh, A., Kamarulzaman, L., \& Zakaria, Z. (2016). The Implementation of Halal Cosmetic Standard in Malaysia: A Brief Overview. In: Ab-Manan, S., Abd-Rahman, F., \& Sahri, M. (eds) Contemporary Issues and Development in the Global Halal Industry. Springer.

[10] Melo, A. V. F., \& Queiroz, A. P. (2019). Bibliometric Mapping of Papers on Geographical Information Systems (2007-2016). Bulletin of Geodetic Sciences, 25(3), 1-16. https://doi.org 10.1590/s1982-21702019000300015 
[11] Mohezar, S., Zailani, S., Zainuddin, Z. (2016). Halal Cosmetics Adoption Among Young Muslim Consumers in Malaysia: Religiosity Concern. Global Journal Al-Thaqafah, 6(1), 47-59.

[12] Ngah, A. H., Ramayah, T., Ali, M. H., Khan, M. I. (2019) Halal Transportation Adoption among Pharmaceuticals and Comestics Manufacturers. Journal of Islamic Marketing. 123. https://.doi.org10.1108JIMA-10-2018-0193

[13] Rahim, N. F., Shafii, Z., \& Shahwan, S. (2015). Awareness and Perception of Muslim Consumers on Halal Cosmetics and Personal Care Products. International Journal of Business, Economics and Management, 2(1), 1-14. https://doi.org 10.18488/journal.62/2015.2.1/62.1.1.14

[14] Samori, Z., Ishak, A. H., Kassan, N. H. (2014). Understanding the Development of Halal Food Standard: Suggestion for Future Research. International Journal of Social Science \& Humanity, 4 (6), 482-486. https://doi.org 10.7763/IJSSH.2014.V4.403

[15] Sugibayashi, K., Yusuf, E., Todo, H., Dahlizar, S., Sakdiset, P., Arce, F. J., See, G. L. (2019). Halal Cosmetics: A Review on Ingredients, Production, and Testing Methods. Cosmetics, 6, 1-17. https://doi.org/10.3390/cosmetics6030037

[16] Sukesi, S., \& Hidayat, W.G.P.A. (2019). Managing the Halal Industry and the Purchase Intention of Indonesian Muslims the Case of Wardah Cosmetics. Journal of Indonesian Islam, 13(1), 200-229. https://doi.org 10.15642/JIIS.2019.13.1.200-229

[17] Tieman, M., Vorst, J. G. A. J., Che Ghazali, M. (2010). Principles in Halal Supply Chain Management. Journal of Islamic Marketing, 3, 217-243. http://dx.doi.org/10.1108/17590831211259727

[18] Zaimah, R., Awang, A. H., Sarmila, M. S., Ishak, S., Azima, A. M., Saad, S., \& Hussain, M. Y. (2018). Consumer's Perceptions and Behaviours towards Halal Food Products in Malaysia. International Journal of Academic Research in Business and Social Sciences, 8 (13 Special Issue: Community Development \& Social Mobility), 151-158. https://doi.org/10.6007/IJARBSS/v8-i13/4819 